\title{
CONSTRUCTION PROBLEMS OF VOLUME PROTECTED BY AIR- TERMINATION ROD FOR THE UKRAINIAN NUCLEAR POWER PLANT UNDER STANDARD EN 62305
}

\author{
O.Ye. Istomin, D.G. Koliushko, S.V. Kiprych, S.S. Rudenko \\ National Technical University "Kharkiv Polytechnical Institute", Kharkiv, Ukraine \\ E-mail:nio5_molniya@ukr.net
}

\begin{abstract}
Mathematical analysis of the rolling sphere method was performed to develop a model for constructing of volume protected by rod air-termination in accordance with EN 62305:2012 for the protection of nuclear power plants objects from direct lightning strike. The necessity of development of the corresponding mathematical model for similar objects is shown, and the direction of its realization with the help of decomposition method is proposed. The mathematical models for calculation of protection zones of single and double air-termination rods of arbitrary height and location are developed. Directions of further researches are formed.
\end{abstract}

PACS: 28.90.+i

\section{PROBLEM FORMULATION}

The lightning protection system at nuclear power plant (NPP) is a complicated configuration system with multiple air-termination rods (ATR) and catenary wires, as well as protective grids installed on roofs of buildings. The main purpose of the lightning protection system at the NPP is to protect against direct lightning strike to ensure the safety of the personnel, the reliability of the equipment operation and the protection of expensive microprocessor equipment in the control system of technological processes. The failure of the NPP equipment due to a direct lightning strike can lead to a current defeat of service staff, significant material damage due to violation of technological processes, downtime of equipment, etc. In addition, the relevance of lightning protection of such objects increases in comparison with objects of a small area, in connection with the increase of thunderstorm activity for the branched system of lightning protection [1].

Lightning protection systems of the vast majority of strategic energy objects of Ukraine, including NPP, are designed in accordance with the standards requirements of the former USSR. Consequently there is a need for its verification and modernization according to the requirements of existing normative documents $[2,3]$.

Authors from 2007 to 2018 have conducted the diagnostics and developed recommendations for the reconstruction of the lightning protection system in accordance with the requirements [2] for a number of power units, buildings and constructions of all operating NPP of Ukraine and an open switchgear with a voltage class of $750 \mathrm{kV}$ of one NPP.

At present, Ukraine has two normative documents in the field of lightning protection of buildings and constructions:

- DSTU B V.2.5-38:2008 Engineering equipment of buildings and constructions. Arrangement of lightning protection of buildings and constructions [2];

- EN 62305-3:2011, IDT Protection against lightning - Part 3: Physical damage to structures and life hazard [3].

The harmonized international lightning protection standard [3] foresees the calculation of protection zone (PZ) of ATR from a direct lightning strike using two methods: a protective angle and rolling sphere.
However, the protective angle method according to [3] is acceptable only for buildings of simple shape and has a limit on the height of ATR. Therefore, only the rolling sphere method can be used to calculate the PZ of ATR system of NPP from a direct lightning strike and their open switchgear. It has more stringent requirements for ATR protection zones than DSTU B V.2.5-38:2008 [2]: PZ of the single ATR with a damage probability of $10 \%$ decreases from 55 to $45 \mathrm{~m}$, and the calculation of lightning protection systems on its basis reduces the probability of lightning damage of the object to be protected. However, engineering techniques of using the rolling sphere method are absent in [3], making its practical application impossible. This leads to the fact that neither lightning protection designers nor NPP operational staff can assess the security of such strategically important objects from direct lightning strike.

The advantages and disadvantages of the existing methods for calculating the PZ ATR and the absence of the necessary mathematical apparatus for calculating the PZ of multiple ATRs are indicated in [4]. The mathematical relationships given in [5-7] for specific cases of ATR location cannot be used to calculate the protection of the complex of buildings and constructions from a lightning strike by the ATR system. In particular, in [5] formulas are given for determining the coordinates of the fictitious sphere center, according to which the sizes of PZ for two ATRs of different heights are uniquely determined, but both ATRs have heights less than the radius of the fictitious sphere. In [6], a number of examples of PZ, constructed by the rolling sphere method, are presented. An algorithm has been developed for constructing the PZ for an arbitrary number of ATRs using the MATLAB software. However, presented expressions and the algorithm make it possible to determine the PZ only in the case of equally high ATRs, the coincidence with which in real life is possible with a rather low probability. That is, only parametric examples, and not general ones, are provided.

In [8], an algorithm was proposed for determining the ATR PZ to protect substation equipment from a direct lightning strike. The expressions for single and double ATRs are obtained, as well the geometric 
solution of this problem is considered in detail. Examples of the PZ construction for a system of four ATR are presented. However, the work presents cases of only equally high ATRs located symmetrically, which is a special case and does not cover all possible combinations. Hence it is not sufficient to determine the PZ of the ATR system of operating NPP. Computer programs, for example, from "Primtech", Pentair, ERICO, Entegra, etc., are used to calculate the ATR PZ of arbitrary heights and locations, but they are a commercial secret of development companies and have some remarks on the calculation results (namely, the form of obtained PZ for lightning protection system).

Thus, the development of a mathematical apparatus and engineering technique for calculating and constructing a PZ for ATR system with complex configuration using the rolling sphere method for existing power energy objects, in particular NPP, according to modern international standards (EN 62305$3: 2012)$ is the scientific and practical task of current interest.

The aim of the work is a mathematical analysis of the rolling sphere method to develop a model for constructing protection zones of a complex system of lightning conductors according to DSTU EN 62305:2012 for protection NPP objects against direct lightning strike.

\section{GENERAL ANALYSIS THE PROTECTION ZONES OF THE AIR-TERMINATION ROD AGAINST DIRECT LIGHTNING STRIKE ACCORDING TO EN 62305-3:2012}

The main method to determine the protection of objects against direct lightning strike is the construction of system ATR. In order to use the lightning protection means (rod and catenary wire) more effectively, all combinations of PZ should be most fully taken into account, for which their mathematical description is necessary. Normative base [3] provides only a general idea of the external view of the PZ (geometry) for two types (single rod and single catenary wire), which is not enough for mathematical modeling of the lightning protection system (multiple catenary wires and rods of arbitrary height and location).

An analysis of the features of the normative base [2, 3] was carried out defining the following:

- the focus on graphical methods for PZ constructing, which causes difficulties with a large number of objects and ATRs, leads to the error probability in geometric constructing and modeling, as well as the interpretation of the results due to the presence of a human factor;

- the lack of a mathematical description for the ATR system, that does not allow in practice to carry out the synthesis and optimization of a lightning protection system.

Due to the presence of various configurations of the lightning protection system at the NPP (double, multiple unequal ATR, inclined catenary wires and their combinations) it is advisable to use special software for
ATR PZ calculation, as indicated in [2, 3]. Therefore, the relevance of creating such a software package comes to the fore, for which you first need to create a mathematical description that is absent in the current normative base.

Therefore, it is possible to identify a number of basic tasks that need to be solved for the design and analysis of the lightning protection of NPP energy objects (open switchgear, buildings and constructions) with an arbitrary ATR configuration:

- creation of a mathematical description of the PZ for all possible forms and types of ATR (rod and catenary wires, single and multiple);

- development of techniques for assessing lightning protection of objects by a complex of various ATRs (any combinations of ATRs and buildings without limiting their number);

- development of techniques for determining the optimal system of lightning protection for a complex of objects using various types of ATRs;

- creation of software products for calculations (design and analysis) of lightning protection systems.

Since the standard [3] gives only a general view of the obtained PZ, there is a need to develop a universal technique for PZ constructing. To solve the problem of constructing a ATR PZ for NPP using the rolling sphere method it is necessary to perform its decomposition, that is, to obtain a general solution it is necessary to obtain the solution to a number of particular problems. To do this, we construct a mathematical model for the PZ of the single and double ATR.

\section{MATHEMATICAL MODEL OF THE PROTECTION ZONE OF SINGLE AIR-TERMINATION ROD}

In the task of constructing a joint PZ, a model of a single ATR zone is a special case, since it is more common to consider a model with more than two ATRs.

For the basis we use solutions of similar problems, considered in [8].

Consider the geometric interpretation of this problem. Fig. 1 shows the vertical and horizontal section for PZ of single ATR.

Geometric model in Fig. 1 is constructed on the basis of the ratio of the ATR height and a given level of lightning protection. The purpose of PZ model constructing is to find the coordinates of the points forming its zone in the space $\left(x_{i}, y_{i}, z_{i}\right)$. For this you need to:

- find the height of PZ $\left(z_{i}\right)$ for known $\mathrm{x}_{\mathrm{i}}$ and $y_{i}$;

- determine the radius of the projection circle of the sphere on the soil plane.

To determine the coordinates $x_{i}, y_{i}, z_{i}$ of any point in the zone, we write the equation of the sphere, which touches the ATR and the soil:

$$
(x-a)^{2}+(y-b)^{2}+(z-c)^{2}=R_{S}^{2},
$$

where $a, b, c$ are coordinates of the sphere center; $R_{S}$ is the sphere radius, which is determined by the level of lightning protection $(20,30,45$ or $60 \mathrm{~m})$ [3]. 


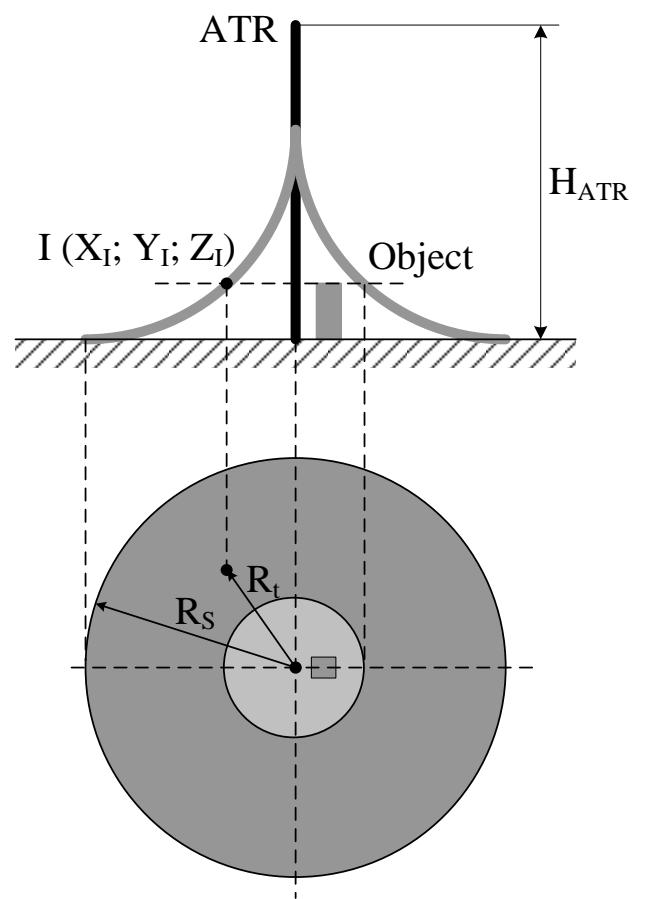

Fig. 1. PZ of a single ATR

Let the coordinates $x_{i}, y_{i}$ of some point $I$ be given and it is necessary to find the coordinate $z_{i}$ of this point belonging to the surface of PZ. Let's calculate the distance from this point to ATR $\left(R_{t}\right)$. Then we get:

$$
R_{t}=\sqrt{\left(x_{m}-x_{i}\right)^{2}+\left(y_{m}-y_{i}\right)^{2}},
$$

where $x_{m}, y_{m}$ are coordinates of ATR location.

Let's calculate the radius of the circle of the sphere projection on the soil plane:

$$
\left\{\begin{array}{l}
R=\sqrt{R_{S}^{2}-\left(R_{S}-H_{A T R}\right)^{2}}, \text { for } H_{A T R}<R_{S}, \\
R=R_{S}, \text { for } H_{A T R} \geq R_{S},
\end{array}\right.
$$

where $H_{A T R}$ is the ATR height.

Then for $R_{t}<R$ we get:

$$
Z_{i}=R_{S}-\sqrt{R_{S}^{2}-\left(R-R_{t}\right)^{2}}
$$

\section{MATHEMATICAL MODEL OF THE PROTECTION ZONE OF DOUBLE AIR-TERMINATION ROD}

As in the case of PZ constructing for a single ATR, the task of obtaining a double ATR is a special case. The geometric model is a problem of finding the coordinates of the protection surface when the sphere simultaneously touches two ATRs. Moreover, the touching of the sphere occurs symmetrically with respect to a straight line passing through the coordinates of ATRs centers.

This task can be reduced to the following. Let it be necessary to find a pair of intersection points $P_{3}$ of two circles formed by the projection of the sphere center on the soil plane during the ATR breaking-in with a sphere of a certain radius corresponding to the accepted level of lightning protection. The geometrical interpretation is shown in Fig. 2. That is, it is necessary to solve the problem of finding the points located at a known distance from a straight line. It is clear that there are two such points $\left(P_{3}\right)$, and they are located symmetrically.

First we find the distance between the centers of the circles $d$ :

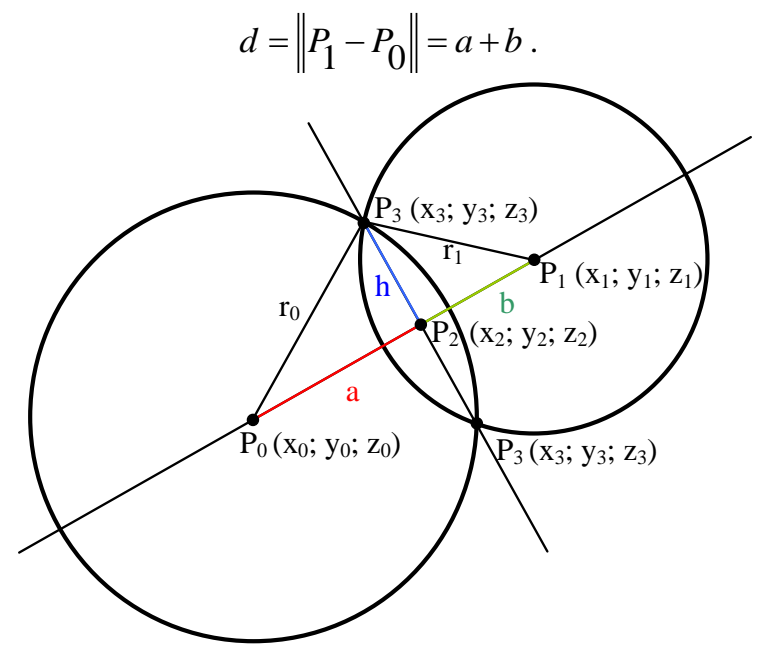

Fig. 2. To the definition of the sphere center, which touches two ATRs

If

$$
d>r_{0}+r_{1}
$$

then there are no intersection points: the circles lie separately. Similarly, in the case of

$$
d<r_{0}-r_{1}
$$

there are no solutions, since one circle is inside the other. In such cases, there is a special case of single ATR. In the case of contact of the circles, that is, $d=r_{0}+r_{1}$, then obviously $a$ is equal to $r_{0}$, and the distance $b=r_{1}$.

If $d<r_{0}+r_{1}$, then we consider two right triangles: $\Delta P_{0} P_{2} P_{3}$ and $\Delta P_{1} P_{2} P_{3}$. We have:

$$
\left\{\begin{array}{l}
a^{2}+h^{2}=r_{0}^{2} \\
b^{2}+h^{2}=r_{1}^{2}
\end{array}\right.
$$

Having solved (4) for $a$, we get:

$$
a=\left(r_{0}^{2}-r_{1}^{2}+d^{2}\right) /(2 d) .
$$

Let's find the coordinates of the point $P_{2}$ by writing the equation of a straight line passing through the points $P_{0}$ and $P_{1}$ :

$$
\begin{aligned}
& x_{2}=x_{0}+a\left(x_{1}-x_{0}\right) / d, \\
& y_{2}=y_{0}+a\left(y_{1}-y_{0}\right) / d .
\end{aligned}
$$

Since the straight line passing through the points $P_{3}$ and $P_{2}$ is orthogonal to the straight line passing through the points $P_{0}$ and $P_{1}$, the coordinates of $P_{3}$ can be found as follows:

$$
\begin{gathered}
x_{3}=x_{2} \pm h\left(y_{1}-y_{0}\right) / d, \\
y_{3}=y_{2} \mp h\left(x_{1}-x_{0}\right) / d, \\
z_{3}=R_{S} .
\end{gathered}
$$

Next, to build the PZ of double ATR, we will consider the geometric model shown in Fig. 3. Points $A_{1}$ and $A_{2}$ are the centers of the sphere projection on the soil if it touches both lightning conductors. 
Let the coordinates $x_{i}, y_{i}$ of a certain point in the Cartesian coordinate system be given, find the coordinate $z_{i}$ of this point belonging to the PZ surface. According to the geometric model, if a point belongs to the region $\mathrm{A}$ or the region $\mathrm{B}$, then the coordinate $z_{i}$ is determined by the expressions (1)-(3).

If the point belongs to the zone $A_{1}$ or $A_{2}$, then the coordinate $z_{i}$ is defined as follows:

$$
z_{i}=R_{S}-\sqrt{R_{S}^{2}-\left(x_{i}-x_{3}\right)^{2}-\left(y_{i}-y_{3}\right)^{2}} .
$$

Thus, in contrast to the results given in [8], the solution was obtained for calculating the PZ for the system of two ATR of arbitrary height (see Fig. 3).
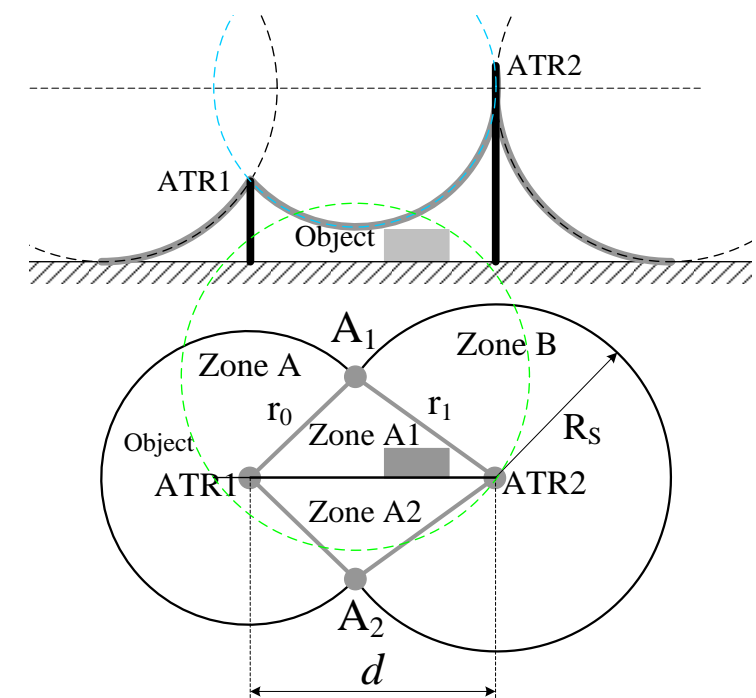

Fig. 3. PZ of double ATR

\section{MATHEMATICAL MODEL OF PROTECTION ZONE WITH COMPLEX CONFIGURATION OF ATR LOCATION}

The special cases considered above make it possible to construct a PZ of ATRs, when the ratio of heights, distances between ATR and a given level of lightning protection do not form a complex configuration of $\mathrm{PZ}$ of these ATRs. However, in most cases, in particular at NPP, a combination of dozens of unequal high ATRs located at different distances from each other leads to the formation of a complex PZ surface. To solve this problem it is necessary to solve a number of subtasks:

- to determine the minimum number of ATRs required to construct the $\mathrm{PZ}$ with a complex configuration of the ATR location on the object's scheme and to create a mathematical model to construct such a PZ;

- to determine the number of ATRs involved in the constructing of a joint PZ, for a given level of lightning protection;

- to make an algorithm for constructing a joint PZ, based on the ATRs location on the scheme and the mathematical description for a specific ATR configuration;
- to construct the geometric and mathematical model for the selected ATR configuration.

\section{CONCLUSIONS}

1. The normative requirements for lightning protection of nuclear power plant in Ukraine are analyzed. The problems that arose in determining the PZ of a lightning protection system with complex configuration using harmonized DSTU EN 623053:2012 are justified.

2. It is proposed to develop a technique for constructing the PZ of a lightning protection system based on the rolling sphere method using the decomposition method. For this purpose, mathematical models have been developed for calculating PZ for single and double ATR of arbitrary height and location.

3. The research directions have been formed and the ways of their solution have been proposed for the development of a mathematical model of the PZ for a system of rod lightning conductors of arbitrary configuration and location.

\section{REFERENCES}

1. M.M. Rezinkina. Technique for predicting the number of lightning strokes to extended objects // Technical Physics. 2008, v. 53, N 5, p. 533-539.

2. DSTU B V.2.5-38:2008. Inzhenerne obladnannya budynkiv $i$ sporud. Ulashtuvannya blyskavkozakhystu budivel' i sporud (IEC 62305:2006 NEC). Vved. 01.01.2009. K.: "Minrehionbud Ukrayiny", 2008. 63 p. (in Ukrainian).

3. EN 62305-3:2011. Protection against lightning Part 3: Physical damage to structures and life hazard.

4. E.M. Bazelyan. Rationing of lightning protection in Russia. Main problems and ways of improvement // III Russian conference on lightning protection, Saint Petersburg, 2012, p. 372-382.

5. V.I. Komarov. On the question of the external lightning protection system designing rolling sphere method // Naukovij oglad. 2014, N 3(4), p. 100-105 (in Ukrainian).

6. K.L.V. Dung. Lightning protection systems design for substations by using masts and Matlab // International Journal of Mathematical, Computational, Physical, Electrical and Computer Engineering. 2010, v. 4, N 5, p. 562-566,

7. G. Berger. Recent considerations on a 3D electrogeometric model and its applications to the PIC DU MIDI // V International conference on lightning protection, St.-Peterburg, May, 2016.

8. Nit Petcharaks. Lightning protection zone in substation using mast // KKU Engineering Journal. 2013, N 40(1), p. 11-20. 


\title{
ПРОБЛЕМАТИКА ПОСТРОЕНИЯ ЗОН ЗАЩИТЫ ДЛЯ АТОМНЫХ ЭЛЕКТРИЧЕСКИХ СТАНЦИЙ УКРАИНЫ ПО СТАНДАРТУ ЕN 62305
}

\section{А.Е. Истомин, Д.Г. Колиушко, С. В. Киприч, С.С. Руденко}

Выполнен математический анализ метода катящейся сферы, для разработки модели построения зон защиты сложной системы молниеотводов согласно ДСТУ EN 62305: 2012 для защиты объектов атомных электрических станций от прямого удара молнии. Показана необходимость разработки соответствующей математической модели для подобных объектов и предложены направление реализации с помощью метода декомпозиции. Разработаны математические модели для расчета зон защиты одиночного и двойного стержневых молниеотводов произвольной высоты и расположения. Сформированы направления для дальнейших исследований.

\section{ПРОБЛЕМАТИКА ПОБУДОВИ ЗОН ЗАХИСТУ БЛИСКАВКОВІДВОДІВ ДЛЯ АТОМНИХ ЕЛЕКТРИЧНИХ СТАНЦІЙ УКРАЇНИ ЗА СТАНДАРТОМ ЕN 62305}

\author{
О.С. Істомін, Д.Г. Коліушко, С.В. Кіприч, С.С. Руденко
}

Виконано математичний аналіз методу сфери, що котиться, для розробки моделі побудови зон захисту складної системи блискавковідводів згідно 3 ДСТУ ЕN 62305:2012 для захисту об'єктів атомних електричних станцій від прямого удару блискавки. Показана необхідність розробки відповідної математичної моделі для подібних об'єктів та запропоновано напрямок іiї реалізації за допомогою методу декомпозиції. Розроблено математичні моделі для розрахунку зон захисту одиничного та подвійного стрижньових блискавковідводів довільної висоти i розташування. Сформовано напрями подальших досліджень. 